\title{
Easy Formation of Nanodisk-Dendritic ZnO Film via Controlled Electrodeposition Process
}

\author{
Nur Azimah Abd Samad, Chin Wei Lai, and Sharifah Bee Abd Hamid \\ Nanotechnology \& Catalysis Research Centre (NANOCAT), 3rd Floor, Block A, Institute of Postgraduate Studies (IPS), \\ University of Malaya, 50603 Kuala Lumpur, Malaysia
}

Correspondence should be addressed to Chin Wei Lai; cwlai@um.edu.my

Received 29 June 2015; Revised 24 September 2015; Accepted 29 September 2015

Academic Editor: Thomas Fix

Copyright (C) 2015 Nur Azimah Abd Samad et al. This is an open access article distributed under the Creative Commons Attribution License, which permits unrestricted use, distribution, and reproduction in any medium, provided the original work is properly cited.

A facile electrodeposition synthesis was introduced to prepare the nanodisk-dendritic $\mathrm{ZnO}$ film using a mixture solution of zinc chloride $\left(\mathrm{ZnCl}_{2}\right)$ with potassium chloride $(\mathrm{KCl})$ that acted as a directing agent. This study aims to determine the best photoelectrochemical response for solar-induced water splitting. Based on our results obtained, it was found that an average diagonal of nanodisk was approximately $1.70 \mu \mathrm{m}$ with the thickness of $\approx 150 \mathrm{~nm}$ that was successfully grown on the surface of substrate. The photocatalytic and photoelectrochemical responses of the resultant wurtzite type based-nanodisk-dendrite $\mathrm{ZnO}$ film as compared to the as-prepared $\mathrm{ZnO}$ film were monitored and evaluated. A photocurrent density of $19.87 \mathrm{~mA} / \mathrm{cm}^{2} \mathrm{under}$ ultraviolet rays and $14.05 \mathrm{~mA} / \mathrm{cm}^{2}$ under visible light $(500 \mathrm{~nm})$ was recorded for the newly developed nanodisk-dendritic $\mathrm{ZnO}$ thin film. It was believed that nanodisk-dendritic $\mathrm{ZnO}$ film can harvest more incident photons from the illumination to generate more photoinduced charge carriers to trigger the photocatalytic and photoelectrochemical reactions. Moreover, strong light scattering effects and high specific surface area of 2D nanostructures aid in the incident light absorption from any direction.

\section{Introduction}

Behind the rapid development of social, economic, and technology, energy becomes a crucial issue around the globe. A global warming devastation occurs from time to time and is becoming severe in the 21st century. Abrupt climate change happens around the world. Intergovernmental Panel on Climate Change (IPCC) is the responsible body to control the global temperature variation; it had announced that the global temperature absolutely increased with the estimation of 0.4 and $0.8^{\circ} \mathrm{C}$ for the past century and this phenomenon was the 10 warmest years over the last 15 years [1]. In the North Atlantic, the atmospheric circulation above Greenland also changed abruptly due to the global warming $[2,3]$. Global warming phenomenon occurred as a result of greenhouse effect which led to the increasing in atmospheric temperature [3]. Increases in concentration of greenhouse gases such as nitrous oxide $\left(\mathrm{N}_{2} \mathrm{O}\right)$, methane $\left(\mathrm{CH}_{4}\right)$, and carbon dioxide $\left(\mathrm{CO}_{2}\right)$ were the main causes of the drought in the areas from East Africa coastal area to the Arabian Sea, South Asia, East Asia, and South China. In the case of water (sea/river) level rising during the 21st century, global warming resulted in the melting of remaining ice masses. IPCC forecasts global mean sea levels (GMSLs) are likely to increase with the variation of $4-5 \mathrm{~mm} /$ year by $2050,0.5-0.9 \mathrm{~m}$ by 2100 , thus the losses of up to $30 \%$ of coastal wetlands [4]. Two major net heat sources had documented (1) net heating generated by human activities and (2) geothermal heat flow. In addition, the exploitation of nuclear energy and nonrenewable energy thus produces an additional heat in the world [5]. These driving forces lead the researchers to reduce the greenhouse effect and environmental protection with presenting creative ideas. In this paper, we are focusing on the alternative energy, hydrogen gas production. Today's hydrogen production is produced from fossil fuels, methane, and coal gasification [6]. The production of hydrogen gas determines the environmental impact and energy efficiency. Light-induced water splitting system is attractive to be studied. Thus, the photocatalysed degeneration of water with nanodisk-dendritic zinc oxide film was chosen to be the catalyst.

Zinc oxide is an n-type semiconductor, with direct wide band gap $(3.37 \mathrm{eV})$ due to its electrons conductivity, and it has 
TABLE 1: The different types of hexagonal $\mathrm{ZnO}$ disk based on preparation method.

\begin{tabular}{|c|c|c|c|}
\hline Researcher & Preparation methods & Findings & References \\
\hline Yin et al. (2014) & $\begin{array}{l}\text { Simple double-solvothermal } \\
\text { method in the presence of glycine }\end{array}$ & $\begin{array}{l}\text { Complex superstructure was } \\
\text { assembled by hexagonal disks; } \\
\text { the thickness of the disk is about } \\
300 \mathrm{~nm}\end{array}$ & {$[25]$} \\
\hline Zeng et al. (2009) & Hydrothermal method & $\begin{array}{l}\text { Uniform single-crystalline } \mathrm{ZnO} \\
\text { nanodisks were well developed } \\
\text { with } 1.5 \mu \mathrm{m} \text { in diameter and } \\
300 \mathrm{~nm} \text { in thickness }\end{array}$ & [17] \\
\hline Zhang et al. (2007) & $\begin{array}{l}\text { Electrodeposition method, } \\
\mathrm{HBO}_{3} \text { as an electrolyte with zinc } \\
\text { foil as anode, voltage } 180 \mathrm{~V} \text {, and } \\
\text { the system kept at } 2^{\circ} \mathrm{C}\end{array}$ & $\begin{array}{l}\text { Zinc/ZnO core-shell hexagonal } \\
\text { nanodisk dendrites were } \\
\text { produced with diameter from } \\
\text { about } 100 \mathrm{~nm} \text { to several hundred } \\
\text { nanometers and thicknesses are } \\
\text { about } 20-40 \mathrm{~nm} \text {. }\end{array}$ & {$[15]$} \\
\hline Li et al. (2007) & $\begin{array}{l}\text { Electrochemical deposition } \\
\text { method }\end{array}$ & $\begin{array}{l}\text { The shape of the } \mathrm{ZnO} \text { dendritic } \\
\text { structure is similar to the branch } \\
\text { of a fern; } \mathrm{ZnO} \text { dendritic } \\
\text { structure is in the range of } \\
6-10 \mu \mathrm{m} \text { and } 200 \mathrm{~nm} \text { of thickness }\end{array}$ & {$[26]$} \\
\hline Xu et al. (2004) & $\begin{array}{l}\text { Vapour phase transport (VPT) } \\
\text { method }\end{array}$ & $\begin{array}{l}\text { Zinc oxide nanodisk; } 3 \mu \mathrm{m} \text { in } \\
\text { diagonal and } 300 \mathrm{~nm} \text { in thickness }\end{array}$ & [21] \\
\hline
\end{tabular}

the wurtzite hexagonal crystal structure. The stoichiometric excess of zinc ions is believed to cause the electrons conductivity where the zinc ions live in interstitial locations in the crystal lattice [7]. The other property of $\mathrm{ZnO}$ is the high exciton binding energy $(60 \mathrm{meV})$ in $\mathrm{ZnO}$ crystal which can produce efficient excitonic emission under room temperature ultraviolet (UV) luminescence [8-10]. Moreover, rectification, optical properties, and chemical properties of $\mathrm{ZnO}$ bring great interest to the research world [9-16]. Synthesis method will determine the crystal shape from acicular needles to plate shaped crystal. By all means, this is the uniqueness of zinc oxide which can be made to form into a variety of crystalline shapes [17]. Furthermore, nearly neutral $(\mathrm{pH} \sim 6)$ system applied to the formation of $\mathrm{ZnO}$ nanostructures supports the environmental protection [17]. According to Table 1, electrochemical deposition method is likely to produce nanodiskdendritic $\mathrm{ZnO}$ and disk-shape morphology is less familiar in research. At the same time, it has unique properties and leads to potential applications such as water-splitting process [18], electrodes for dye sensitized solar cells [19], and nanosensors $[20,21]$. Equally important, the low active surface area and fast recombination losses of photoinduced charge carriers remain as a great challenge for $\mathrm{ZnO}$ nanostructures. Therefore, in this paper, the formation of nanodisk-dendritic zinc oxide was studied. The ability of nanodisk-dendritic $\mathrm{ZnO}$ photoelectrode in current-voltage characteristics and methyl orange (MO) degradation also has been studied.

\section{Experimental Section}

2.1. Synthesis of Nanodisk-Dendritic $\mathrm{ZnO}$. ZnO nanostructures films were produced by electrodeposition process of zinc $(\mathrm{Zn})$ foil (thickness $0.25 \mathrm{~mm}, 99.9 \%$ trace metals basis, Sigma-Aldrich) in a bath with electrolytes composed of $50 \mathrm{~mL}$ of $0.5 \mathrm{mM}$ zinc chloride $\left(\mathrm{ZnCl}_{2}\right)$ and $50 \mathrm{~mL}$ of $0.1 \mathrm{M}$ potassium chloride $(\mathrm{KCl})$ at $3.0 \mathrm{~V}$ at temperature of $80^{\circ} \mathrm{C}$. From our literature studies, $3.0 \mathrm{~V}$ and $80^{\circ} \mathrm{C}$ were selected in our study because the polycrystalline structure of $\mathrm{ZnO}$ will start to evolve at this potential difference and temperature with obviously and randomly oriented grains. The as-prepared $\mathrm{pH}$ of electrolyte is about 5-6, which was measured using a $\mathrm{pH}$ meter Mettler Toledo InLab Expert Pro. The electrodeposition process was conducted with two-electrode configuration system, where platinum electrode served as anode and $\mathrm{Zn}$ foil served as cathode. This closed system was then connected to a DC power supply. After electrodeposition process, the nanodeposit has been rinsed thoroughly with acetone for analysis Emsure Acs, Iso, Reag. Ph Eur for analysis and dried at atmosphere. The deposited $\mathrm{ZnO}$ nanostructured film was then annealed at $600^{\circ} \mathrm{C}$ for 3 hours because the zinc peaks will be negligible and completely oxidised [15].

2.2. Characterizations of Nanodisk-Dendritic $\mathrm{ZnO}$. The crystallinity and phase transition of the samples were analyzed by using Bruker D8 Advance equipped with EVA-Diffract Software (Germany) X-ray Diffraction (XRD) with $\mathrm{Cu} \mathrm{K}_{\alpha}$ radiation and wavelength $\lambda=1.5418 \AA$. Meanwhile, the surface and cross-sectional morphologies of the samples have been viewed by Field Emission Scanning Electron Microscopy (FESEM) Quanta FEG 450 and the elemental analysis of $\mathrm{ZnO}$ nanostructured film was determined with Hitachi Energy Dispersive X-Ray Spectroscopy (EDX) analysis.

To study the photocurrent density of the sample, a threeelectrode PEC cell with nanodisk-dendritic $\mathrm{ZnO}$ film served as anode, a platinum rod as the cathode, and a saturated calomel electrode (SCE) as the reference electrode arranged in a quarts cell filled with $1 \mathrm{M}$ sodium hydroxide $(\mathrm{NaOH})$ containing $1 \mathrm{v} \%$ of ethylene glycol. A $150 \mathrm{~W}$ xenon lamp (Zolix 


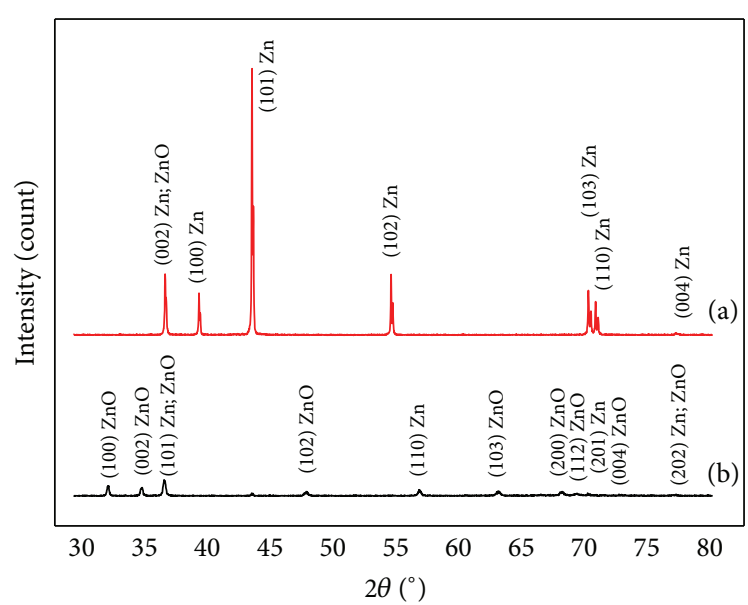

FIGURE 1: XRD pattern of (a) as-prepared $\mathrm{ZnO}$ and (b) annealed nanodisk-dendritic $\mathrm{ZnO}$.

LSP-X150) was set to focus on the immersed portion of the photoelectrode to stimulate solar irradiation. The three electrodes were connected to the potentiostat (Metrohm Autolab PGSTAT204); the current-voltage value was measured. The photocurrent density has been measured by using Metrohm Autolab PGSTAT204, with linear sweep voltammetry potentiostatic procedure (-1 to $1 \mathrm{~V}$ potential applied). Photocatalytic degradation studies were implemented by dipping the nanodisk-dendritic $\mathrm{ZnO}$ thin film in $100 \mathrm{~mL}$ of 15 parts per million (ppm) of methyl orange (MO) solution in a quartz glass tube and placed in the photoreactor. The samples were photoilluminated at room temperature by using TUV $18 \mathrm{~W}$ UV-C Germicidal light. After leaving it in a reactor for 30 minutes in dark environment, $5 \mathrm{~mL}$ solution was withdrawn for every 1 hour from the quartz tubes to study the degradation of methyl orange (MO) after UV irradiation. A UVVis Spectrophotometer (UV-3101PC Shimadzu) was used to analyze the degradation percentage of $\mathrm{MO}$ solution.

\section{Results and Discussion}

3.1. Phase Transformation for Nanodisk-Dendritic $\mathrm{ZnO}$. In this part of experiment, $\mathrm{XRD}$ analysis was used to investigate the crystallinity of the nanodisk-dendritic $\mathrm{ZnO}$ thin film and as-prepared $\mathrm{ZnO}$ thin film as presented in Figure 1. The XRD pattern of the as-prepared $\mathrm{ZnO}$ thin film exhibited major $\mathrm{Zn}$ phase, which points to the existence of amorphous nature (Figure 1(a)). The Bragg reflection of $\mathrm{Zn}$ phase was detected at $2 \theta$ values of $36.30^{\circ}, 39.00^{\circ}, 43.23^{\circ}, 54.33^{\circ}, 70.08^{\circ}, 70.65^{\circ}$, and $77.02^{\circ}$ in entire XRD patterns, corresponding to (002), (100), (101), (102), (013), (110), and (004) crystal planes, respectively. The presence of $\mathrm{Zn}$ phase was identified by ICDD file of 00-004-0831. Meanwhile, for nanodisk-dendritic $\mathrm{ZnO}$ thin film (Figure 1(b)), the result showed that the samples were in line with reference code ICDD 00-036-1451 which indicates the $\mathrm{ZnO}$ phase. The Bragg reflection of $\mathrm{ZnO}$ phase was detected at $2 \theta$ values of $31.75^{\circ}, 34.51^{\circ}, 36.31^{\circ}, 47.60^{\circ}, 62.29^{\circ}$, $66.41^{\circ}, 67.94^{\circ}, 70.02^{\circ}$, and $77.0^{\circ}$ in entire XRD patterns, corresponding to (100), (002), (101), (102), (103), (200), (112),
TABLE 2: Average compositional ratio of nanodisk-dendritic $\mathrm{ZnO}$ and as-prepared $\mathrm{ZnO}$ using EDX spectroscopy analysis.

\begin{tabular}{lcc}
\hline \multirow{2}{*}{ Element } & \multicolumn{2}{c}{ Atomic percentage (\%) } \\
& Nanodisk-dendritic ZnO & As-prepared ZnO \\
\hline Zinc & 42.59 & 84.32 \\
Oxygen & 57.41 & 15.68 \\
\hline
\end{tabular}

(004), and (202) crystal planes, respectively. It showed that the sample was crystallized and uniform lattice strain was obtained after calcination process. All peaks were shifted to the left as the $\mathrm{ZnO}$ crystals were well and denser after calcination process. In addition, the nanodisk-dendritic $\mathrm{ZnO}$ sample is matched with the chemical formula $\mathrm{ZnO}$ (referring to $\mathrm{XRD}$ test) and consists of hexagonal crystal system. Besides, it also matched the wurtzite type because $a=3.2498 \AA, b=$ $3.2498 \AA$, and $c=5.2066 \AA$. The wurtzite type is important in semiconductor application as compared to other crystal structures of $\mathrm{ZnO}$ : zinc blende and rocksalt. The significance of wurtzite type $\mathrm{ZnO}$ was obtained from the ideal arrangement, by changing the $c / a$ ratio or the $u$ value. From experimental observation, $c / a$ ratios are smaller than ideal ones. In addition, $c / a$ ratio also showed the association of difference for two constituents' electronegativity. Consequently, components with the greatest difference show largest departure from the ideal $c / a$ ratio [22-24].

3.2. Morphological Structure of Nanodisk-Dendritic $\mathrm{ZnO}$. Substrate was shrill of nanodisk-dendritic $\mathrm{ZnO}$ (Figure 2(a)). The nanodisk-dendritic zinc oxides have a perfect hexagonal shape with diagonal of approximately $1.7 \mu \mathrm{m}$ and thickness of approximately $150.4 \mathrm{~nm}$. This result is in line with past researches at which nanodisk-dendritic $\mathrm{ZnO}$ exhibits unique characteristics and consists of overlapping nanodisks and self-tiered structure [15]. The stem and the leaflets were built of hexagonal nanodisks where they were self-arranged and self-assembled and became little leaves. The EDX spectroscopy analysis was performed and it showed average atomic percentage of $42.59 \%$ and $57.41 \%$ of zinc and oxygen, respectively, for nanodisk-dendritic $\mathrm{ZnO}$ and average atomic percentage of $84.32 \%$ and $15.68 \%$ of zinc and oxygen, respectively, for as-prepared $\mathrm{ZnO}$ (Table 2). In this study, two-step process took place under dynamic electrolyte for the formation of nanodisk-dendritic $\mathrm{ZnO}$. The first step was the formation of zinc hydroxide $\left(\mathrm{Zn}(\mathrm{OH})_{2}\right)$, followed by formation of zinc oxide $(\mathrm{ZnO})$. However, this process occurred at all time until the reaction stopped. In the first place, the process started with dissolution of zinc chloride, potassium chloride and water to potassium ion $\left(\mathrm{K}^{+}\right)$, zinc ion $\left(\mathrm{Zn}^{2+}\right)$, chloride ion $\left(\mathrm{Cl}^{-}\right)$, and hydroxide ion $\left(\mathrm{OH}^{-}\right)$and formation of hydrogen gas $\left(\mathrm{H}_{2}\right)$ occurred in the electrolyte by electrochemical process with energy supplied from direct electric current that separated the electrolyte into ions [27, 28] (1). Second, for the formation of zinc hydroxide $\left(\mathrm{Zn}(\mathrm{OH})_{2}\right)$ (intermediate growth stage), the $\mathrm{K}^{+}$(as directing agent) attracted the $\mathrm{OH}^{-}$ to the cathode and produced increases in local $\mathrm{pH}$, and saturation level changed at the cathode. When a supersaturation condition is reached, the nucleation of $\mathrm{Zn}(\mathrm{OH})_{2}$ precipitation 


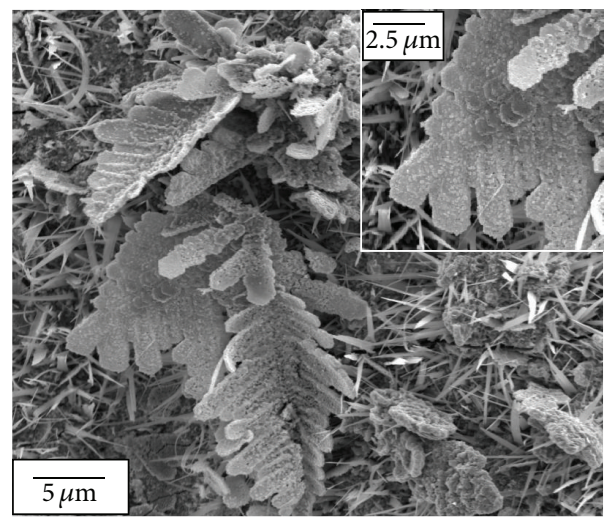

(a)

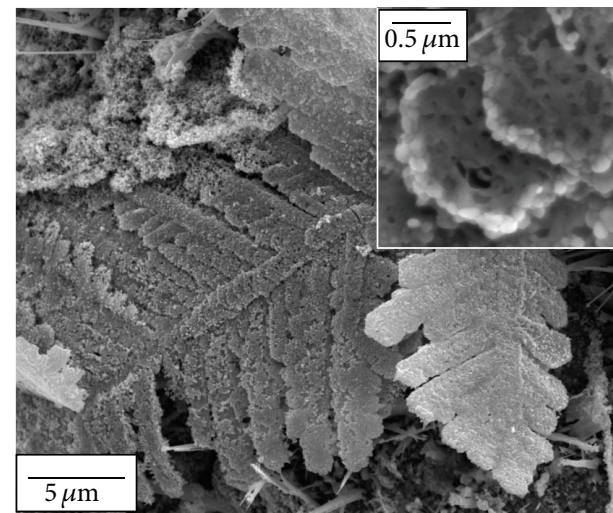

(b)

FIGURE 2: FESEM image of (a) $\times 6 \mathrm{k}$ magnification of nanodisk-dendritic $\mathrm{ZnO}$; (inset) $\times 20 \mathrm{k}$ magnification of stacked hexagonal-shape nanodisk $\mathrm{ZnO}$ and (b) $\times 10 \mathrm{k}$ magnification of nanodisk-dendritic $\mathrm{ZnO}$; (inset) $\times 100 \mathrm{k}$ magnification hexagonal-shape nanodisk $\mathrm{ZnO}$.

occurred on the substrate surface (cathode) (2). The formation of zinc oxide $(\mathrm{ZnO})$ occurred by dehydration process of $\mathrm{Zn}(\mathrm{OH})_{2}$ on the substrate (3). At the beginning of deposition process, the $\mathrm{Zn}^{2+}$ concentration at the substrate surface decreased when $\mathrm{pH}$ is increased leading to slowest growth rate towards (0001). Diffusion of $\mathrm{Zn}^{2+}$ from (0001) to the substrate surface leads to the unit growing at preferential growth of [1000] direction. When many nanodisks stacked together, it is important to realize that their arrangements on the substrate were on horizontal position (1000) which is in the $x$-axis direction and it is clearly seen in symmetry shape. The crystal growth velocity along various planes depended on the atomic packing density [15]. (Figure 2(a) inset and Figure 2(b) inset). Below are the equations related to the formation of $\mathrm{ZnO}$ :

Dissolution of $\mathrm{KCl}+\mathrm{ZnCl}_{2}+\mathrm{H}_{2} \mathrm{O}$ is as follows:

$$
\begin{gathered}
\mathrm{KCl} \longrightarrow \mathrm{K}^{+}(\mathrm{aq})+\mathrm{Cl}^{-}(\mathrm{aq}) \\
\mathrm{ZnCl}_{2} \longrightarrow \mathrm{Zn}^{2+}(\mathrm{aq})+2 \mathrm{Cl}^{-}(\mathrm{aq}) \\
2 \mathrm{H}_{2} \mathrm{O} \longrightarrow \mathrm{H}_{2} \uparrow+2 \mathrm{OH}^{-}(\mathrm{aq})
\end{gathered}
$$

Formation of zinc hydroxide $\left(\mathrm{Zn}(\mathrm{OH})_{2}\right), \mathrm{KOH}$, and $\mathrm{KCl}$ is as follows:

$$
\begin{aligned}
& \mathrm{K}^{+}(\mathrm{aq})+\mathrm{OH}^{-}(\mathrm{aq}) \longrightarrow \mathrm{KOH} \\
& \mathrm{Zn}^{2+}(\mathrm{aq})+2 \mathrm{OH}^{-}(\mathrm{aq}) \longrightarrow \mathrm{Zn}(\mathrm{OH})_{2} \\
& \mathrm{H}_{2} \uparrow+2 \mathrm{Cl}^{-} \longrightarrow 2 \mathrm{HCl}
\end{aligned}
$$

Formation of zinc oxide $(\mathrm{ZnO})$ is as follows:

$$
\begin{aligned}
\mathrm{Zn}(\mathrm{OH})_{2} & \longrightarrow \mathrm{ZnO}+\mathrm{H}_{2} \mathrm{O} \text { (dehydration process) } \\
\mathrm{HCl}+\mathrm{KOH} & \longrightarrow \mathrm{H}_{2} \mathrm{O}+\mathrm{KCl}
\end{aligned}
$$

Past researches found the formation of dendrite shape due to the fast growth velocity of $\mathrm{Zn}$ ion in the electrolyte [29, 30].
Growth mechanism occurred in global diffusion and later oriented attachments were localized. Dislocation from the early crystal growth happened due to the high velocity of electrolyte (>350 rpm). Therefore, the second hexagonal nanodisk has grown slightly dislocated from the earlier crystal. Another key point is that nanodisk-dendritic tips were known to grow in the direction of maximum surface energy. The (1000) facet was out of sorts; therefore it contributed to highest effective surface energy $[15,31]$.

3.3. Photocatalytic Activity Evaluation. The photocatalytic activities of the nanodisk-dendritic $\mathrm{ZnO}$ and as-prepared $\mathrm{ZnO}$ were investigated using the $\mathrm{MO}$ degradation method under UV light radiation with the purpose to support the photocatalytic activity argument of nanodisk-dendritic $\mathrm{ZnO}$. It was confirmed that nanodisk-dendritic $\mathrm{ZnO}$ exhibited good photocatalytic property when MO solution was degraded for approximately $80 \%$ after 6 hours under UV irradiation. Nanodisk-dendritic $\mathrm{ZnO}$ exhibited higher photocatalytic activity compared to as-prepared $\mathrm{ZnO}$ with $\mathrm{MO}$ concentration $18 \%$ after 6 hours (Figure 3(a)). Decomposition of MO solution can be explained by an oxidation process that took place on the surface of nanodisk-dendritic $\mathrm{ZnO}$ via photogenerated hole. In other words, an electron-hole pair existed in the absence of light intensity [32-34]. Under UV light illumination, energy produced was higher than nanodisk-dendritic $\mathrm{ZnO}$ band gap energy. Therefore, electrons at the conduction band and holes at the valence band were generated. Holes at the nanodisk-dendritic $\mathrm{ZnO}$ surfaces react with water to form highly reactive hydroxyl radicals $\left(\mathrm{OH}^{*}\right)$, and at the same time oxygen acts as an electron acceptor by being a superoxide radical anion [35]. The superoxide radical anions from hydroxyl radicals have an excellent oxidation ability [36] which may degrade organic dye, and, in MO decomposition, it was degraded to carbon dioxide and water [31]. Nanodisk-dendritic $\mathrm{ZnO}$ showed high photocatalytic property due to its high surface area and active photoresponse (2D structure). 


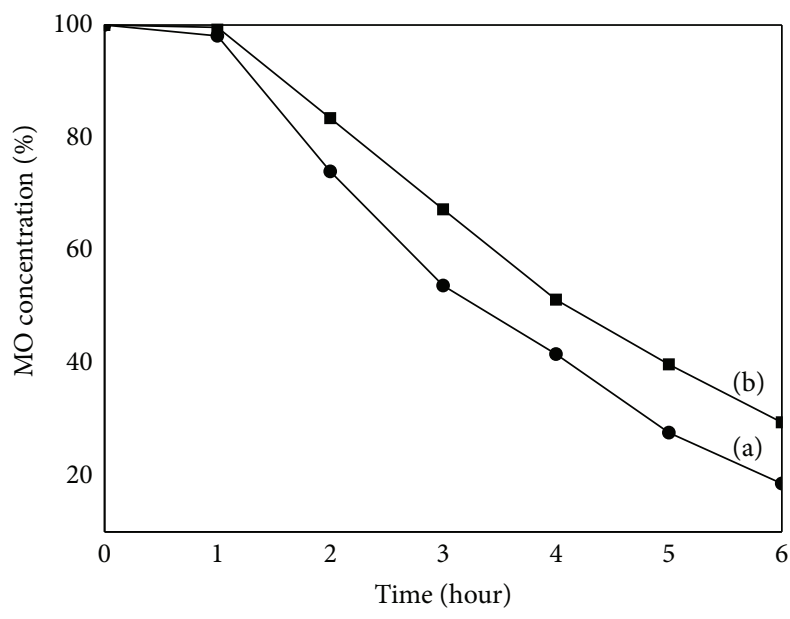

FIGURE 3: Photodegradation of MO solution by (a) nanodiskdendritic $\mathrm{ZnO}$ and (b) as-prepared $\mathrm{ZnO}$ with increasing degradation time.

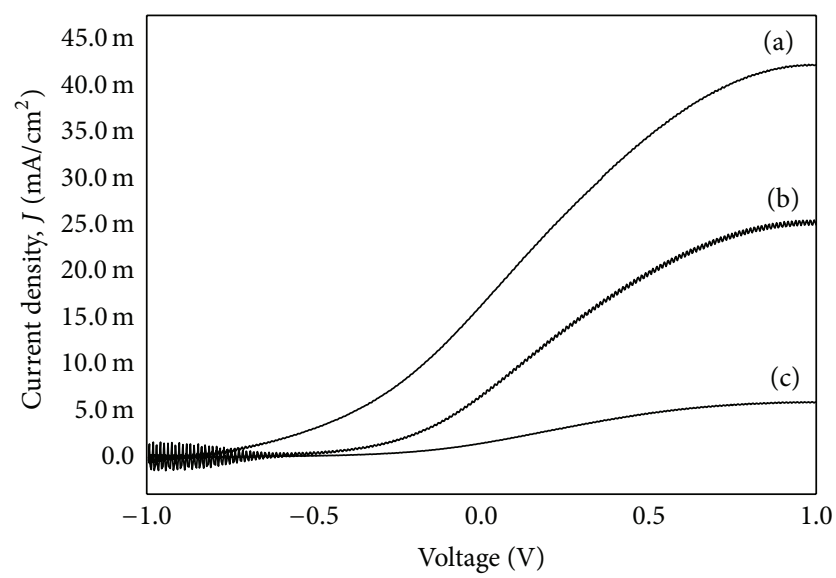

FIGURE 4: Current density-voltage characteristics for (a) nanodiskdendritic $\mathrm{ZnO}$ and (b) as-prepared $\mathrm{ZnO}$ under ultraviolet ray and (c) nanodisk-dendritic $\mathrm{ZnO}$ without illumination.

3.4. Photoelectrochemical Response. A scanning potentiostat by mean to measure current $(I)$ under an applied potential $(V)$ could test the efficiency of nanodisk-dendritic $\mathrm{ZnO}$ photocatalytic activity. For water electrolysis application, the efficiencies of over $90 \%$ are at -1 to $1 \mathrm{~V}[37,38]$. From now on, in order to understand the efficiency nanodiskdendritic $\mathrm{ZnO}$ thin films in water electrolysis, sample was evaluated and tested their $I-V$ characteristics between $-1 \mathrm{~V}$ and $1 \mathrm{~V}$. Figure 4 was plotted to exhibit $I-V$ characteristic curves for the (a) nanodisk-dendritic $\mathrm{ZnO}$, (b) as-prepared $\mathrm{ZnO}$ under ultraviolet ray, and (c) nanodisk-dendritic $\mathrm{ZnO}$ without illumination. The significant photocurrent density $j_{p}$ of an average value of $19.87 \mathrm{~mA} / \mathrm{cm}^{2}$ for nanodisk-dendritic $\mathrm{ZnO}$ under ultraviolet ray (Figure 4(a)) was obtained as compared to $6.45 \mathrm{~mA} / \mathrm{cm}^{2}$ for as-prepared $\mathrm{ZnO}$ under ultraviolet ray (Figure $4(\mathrm{~b})$ ) and $1.49 \mathrm{~mA} / \mathrm{cm}^{2}$ for nanodisk-dendritic $\mathrm{ZnO}$ without illumination (Figure 4(c)). The catalytic activity contribution can be observed from photocurrent density

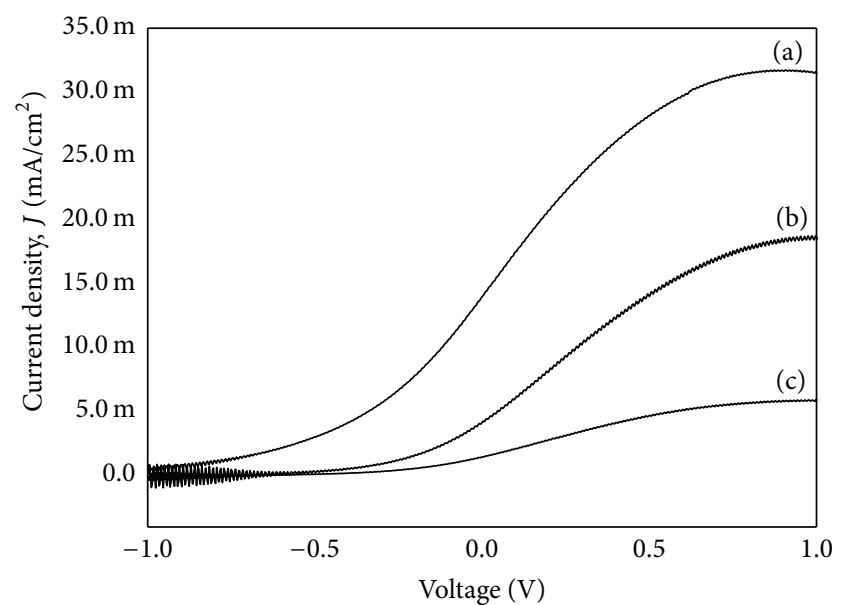

FIGURE 5: Current density-voltage characteristics for (a) nanodiskdendritic $\mathrm{ZnO}$, (b) as-prepared $\mathrm{ZnO}$ under visible light, and (c) nanodisk-dendritic $\mathrm{ZnO}$ without illumination.

differences under ultraviolet ray illumination and without ultraviolet ray illumination. However, the current density $j$ value decreased with the increasing of spectrum wavelength until visible light spectrum $(390-700 \mathrm{~nm})$ is reached. Under visible light, average $j_{p}$ of $14.05 \mathrm{~mA} / \mathrm{cm}^{2}$ was observed for the nanodisk-dendritic $\mathrm{ZnO}$ (Figure 5(a)), which is relatively higher when compared to as-prepared $\mathrm{ZnO}$ under visible light: $j_{p} 2.14 \mathrm{~mA} / \mathrm{cm}^{2}$ (Figure 5(b)) and nanodisk-dendritic $\mathrm{ZnO}$ without illumination: $1.49 \mathrm{~mA} / \mathrm{cm}^{2}$ (Figure 5(c)).

Based on the results of $j$ - $V$ characteristic curves (Figures 4 and 5), as-prepared- $\mathrm{ZnO}$ film showed poor result due to the existence of oxygen vacancies inside the $\mathrm{ZnO}$ bulk, which points to the increasing number of recombination centers. The recombination centers clearly contributed to the decreasing of photoinduced $\mathrm{e}^{-}$mobility and back to the contact of $\mathrm{Zn}$ substrate because of series of resistance caused by increasing trap states. Besides, the amorphous phase comprises high concentration of other material defects such as impurities, dangling bonds, and microvoids, which similarly act as recombination center and result in a decrease of $j_{p}$ [39]. Predominantly, as-prepared- $\mathrm{ZnO}$ film is basically unable to develop a regular depletion region [40]. It was found that the $j_{p}$ of heat treated $\left(600^{\circ} \mathrm{C}\right)$ nanodisk-dendritic $\mathrm{ZnO}$ sample was slightly increased to $19.87 \mathrm{~mA} / \mathrm{cm}^{2}$, which suggests that crystal structure of nanodisk-dendritic $\mathrm{ZnO}$ sample can improve the photocurrent generation effectively. In addition, the high specific surface area of nanodisk-dendritic architecture might have contributed to the strong light scattering effects and incident light absorption from any direction. In the electrolyte, the large active surface area established the photoinduced electrons and these electrons transferred to the substrate. By the use of external circuit, the photoinduced electron travels to counter electrode (platinum electrode) and enhances the photocatalytic activity and photoelectrochemical response significantly. 


\section{Conclusions}

In this paper, nanodisk-dendritic $\mathrm{ZnO}$ with perfect hexagonal shape was fabricated by a simple one-step electrodeposition process with $600^{\circ} \mathrm{C}$ calcination temperature. From the characterization methods, it indicates that the sample is nanodisk-dendritic zinc oxide; with chemical formula, $\mathrm{ZnO}$, and consists of hexagonal crystal system. It lies under tetragonal wurtzite type because $a=3.2498 \AA, b=3.2498 \AA$, and $c=5.2066 \AA$. The photocatalytic test (photocurrent density and methyl orange degradation) confirmed that nanodiskdendritic zinc oxide has excellent photocatalytic activity. Prolonged electrodeposition time or increase of the $\mathrm{ZnCl}_{2}$ concentration may increase the volume of nanodisk-dendritic $\mathrm{ZnO}$ and produce better photocatalytic activity.

\section{Conflict of Interests}

The authors declare that there is no conflict of interests regarding the publication of this paper.

\section{Acknowledgments}

The authors would like to thank University of Malaya for funding this research work under University of Malaya Research Grant (UMRG, RP022-2012D), Fundamental Research Grant Scheme (FRGS, FP055-2013B), and Postgraduate Research Fund Scheme (PPP, PG058-2014B). In addition, they would like to acknowledge Nippon Sheet Glass Foundation for Materials Science and Engineering (IF001-2015) for funding this research work.

\section{References}

[1] United States Environmental Protection Agency (EPA), Global Warming, United States Environmental Protection Agency (EPA), 2001.

[2] G. Bond, W. Showers, M. Cheseby et al., "A pervasive millennialscale cycle in North Atlantic Holocene and glacial climates," Science, vol. 278, no. 5341, pp. 1257-1266, 1997.

[3] J.-B. Huang, S.-W. Wang, Y. Luo, Z.-C. Zhao, and X.-Y. Wen, "Debates on the causes of global warming," Advances in Climate Change Research, vol. 3, no. 1, pp. 38-44, 2012.

[4] R. J. Devoy, "Sea-level rise: causes, impacts, and scenarios for change," in Coastal and Marine Hazards, Risks, and Disasters, pp. 197-241, Elsevier, 2014.

[5] B. Nordell, "Thermal pollution causes global warming," Global and Planetary Change, vol. 38, no. 3-4, pp. 305-312, 2003.

[6] J. M. Ogden, "Prospects for building a hydrogen energy infrastructure," Annual Review of Energy and the Environment, vol. 24, no. 1, pp. 227-279, 1999.

[7] G. Vijayasarathi, "Alternate energy source using plants instead of photo-voltaic cell-an innovative solution for power crisis," International Journal of Engineering Research \& Technology, vol. 1, no. 8, pp. 1-6, 2012.

[8] S. Roy and S. Basu, "Improved zinc oxide film for gas sensor applications," Bulletin of Materials Science, vol. 25, no. 6, pp. 513$515,2002$.

[9] Y. C. Kong, D. P. Yu, B. Zhang, W. Fang, and S. Q. Feng, "Ultraviolet-emitting $\mathrm{ZnO}$ nanowires synthesized by a physical vapor deposition approach," Applied Physics Letters, vol. 78, no. 4, pp. 407-409, 2001.

[10] Z. L. Wang, "Zinc oxide nanostructures: growth, properties and applications," Journal of Physics: Condensed Matter, vol. 16, no. 25, pp. R829-R858, 2004.

[11] S. Xu and Z. L. Wang, "One-dimensional ZnO nanostructures: solution growth and functional properties," Nano Research, vol. 4, no. 11, pp. 1013-1098, 2011.

[12] M. Abd-Ellah, N. Moghimi, L. Zhang et al., "Effect of electrolyte conductivity on controlled electrochemical synthesis of zinc oxide nanotubes and nanorods," The Journal of Physical Chemistry C, vol. 117, no. 13, pp. 6794-6799, 2013.

[13] C. J. Lee, T. J. Lee, S. C. Lyu, Y. Zhang, H. Ruh, and H. J. Lee, "Field emission from well-aligned zinc oxide nanowires grown at low temperature," Applied Physics Letters, vol. 81, no. 19, pp. 3648-3650, 2002.

[14] J. Zhang, M. Matsuoka, J. Sung Lee, and S. Chen, "Development of visible light-responsive photocatalysts," International Journal of Photoenergy, vol. 2012, Article ID 280297, 4 pages, 2012.

[15] X. Y. Zhang, J. Y. Dai, C. H. Lam et al., "Zinc/ZnO core-shell hexagonal nanodisk dendrites and their photoluminescence," Acta Materialia, vol. 55, no. 15, pp. 5039-5044, 2007.

[16] Y. Zhang, N. Wang, S. Gao et al., "A simple method to synthesize nanowires," Chemistry of Materials, vol. 14, no. 8, pp. 3564-3568, 2002.

[17] J. H. Zeng, B. B. Jin, and Y. F. Wang, "Facet enhanced photocatalytic effect with uniform single-crystalline zinc oxide nanodisks," Chemical Physics Letters, vol. 472, no. 1-3, pp. 90-95, 2009.

[18] S.-Y. Guo, S. Han, B. Chi, J. Pu, and J. Li, "Synthesis of shapecontrolled mesoporous titanium phosphate nanocrystals: the hexagonal titanium phosphate with enhanced hydrogen generation from water splitting," International Journal of Hydrogen Energy, vol. 39, no. 6, pp. 2446-2453, 2014.

[19] Q. Zhang, C. S. Dandeneau, X. Zhou, and C. Cao, “ZnO nanostructures for dye-sensitized solar cells," Advanced Materials, vol. 21, no. 41, pp. 4087-4108, 2009.

[20] V. Germain, A. Brioude, D. Ingert, and M. P. Pileni, "Silver nanodisks: size selection via centrifugation and optical properties," The Journal of Chemical Physics, vol. 122, no. 12, Article ID 124707, 2005.

[21] C. X. Xu, X. W. Sun, Z. L. Dong, and M. B. Yu, "Zinc oxide nanodisk," Applied Physics Letters, vol. 85, no. 17, pp. 3878-3880, 2004.

[22] J. L. G. Fierro, Metal Oxides: Chemistry and Applications, CRC Press, 2010.

[23] E. H. Kisi and M. M. Elcombe, "u parameters for the wurtzite structure of $\mathrm{ZnS}$ and $\mathrm{ZnO}$ using powder neutron diffraction," Acta Crystallographica-Section C: Crystal Structure Communications, vol. 45, no. 12, pp. 1867-1870, 1989.

[24] M. O. Manasreh, III-Nitride Semiconductors: Electrical, Structural and Defects Properties, Elsevier, Amsterdam, The Netherlands, 2000.

[25] J. Yin, F. Gao, C. Wei, and Q. Lu, "Water amount dependence on morphologies and properties of $\mathrm{ZnO}$ nanostructures in doublesolvent system," Scientific Reports, vol. 4, article 3736, 2014.

[26] G.-R. Li, X.-H. Lu, D.-L. Qu et al., "Electrochemical growth and control of $\mathrm{ZnO}$ dendritic structures," Journal of Physical Chemistry C, vol. 111, no. 18, pp. 6678-6683, 2007.

[27] B. Boddenberg, "Concepts in physical chemistry," Zeitschrift für Physikalische Chemie, vol. 195, part 1-2, pp. 287-289, 1996. 
[28] J. M. Barthel, H. Krienke, and W. Kunz, Physical Chemistry of Electrolyte Solutions: Modern Aspects, vol. 5, Springer Science \& Business Media, 1998.

[29] M. E. Perel'man, G. M. Rubinstein, and V. A. Tatartchenko, "Mechanisms of dendrites occurrence during crystallization: features of the ice crystals formation," Physics Letters A, vol. 372, no. 22, pp. 4100-4103, 2008.

[30] J. Xue, W. Liang, X. Liu, Q. Shen, and B. Xu, "Crystallization behavior and formation mechanism of dendrite $\mathrm{Cu}_{2} \mathrm{O}$ crystals," CrystEngComm, vol. 14, no. 23, pp. 8017-8022, 2012.

[31] M. R. Hoffmann, S. T. Martin, W. Choi, and D. W. Bahnemann, "Environmental applications of semiconductor photocatalysis," Chemical Reviews, vol. 95, no. 1, pp. 69-96, 1995.

[32] N. Jain, A. Bhargava, and J. Panwar, "Enhanced photocatalytic degradation of methylene blue using biologically synthesized 'protein-capped' $\mathrm{ZnO}$ nanoparticles,' Chemical Engineering Journal, vol. 243, pp. 549-555, 2014.

[33] S.-M. Lam, J.-C. Sin, A. Z. Abdullah, and A. R. Mohamed, "Degradation of wastewaters containing organic dyes photocatalysed by zinc oxide: a review," Desalination and Water Treatment, vol. 41, no. 1-3, pp. 131-169, 2012.

[34] C.-J. Lin, Y.-T. Lu, C.-H. Hsieh, and S.-H. Chien, "Surface modification of highly ordered $\mathrm{TiO}_{2}$ nanotube arrays for efficient photoelectrocatalytic water splitting," Applied Physics Letters, vol. 94, no. 11, Article ID 113102, 2009.

[35] S.-Y. Pung, W.-P. Lee, and A. Aziz, "Kinetic study of organic dye degradation using $\mathrm{ZnO}$ particles with different morphologies as a photocatalyst," International Journal of Inorganic Chemistry, vol. 2012, Article ID 608183, 9 pages, 2012.

[36] X. Jia, M. Tian, Y. Liu, X. Wu, and H. Song, "In situ precipitation preparation of $\mathrm{ZnO}$ hollow spheres and their photocatalysis and gas-sensing properties," Applied Physics A, vol. 119, no. 3, pp. 1179-1185, 2015.

[37] S. Licht, B. Wang, S. Mukerji, T. Soga, M. Umeno, and H. Tributsch, "Efficient solar water splitting, exemplified by $\mathrm{RuO}_{2}-$ catalyzed AlGaAs/Si photoelectrolysis," The Journal of Physical Chemistry B, vol. 104, no. 38, pp. 8920-8924, 2000.

[38] S. Licht, B. Wang, S. Mukerji, T. Soga, M. Umeno, and H. Tributsch, "Over 18\% solar energy conversion to generation of hydrogen fuel; theory and experiment for efficient solar water splitting," International Journal of Hydrogen Energy, vol. 26, no. 7, pp. 653-659, 2001.

[39] C. W. Lai and S. Sreekantan, "Photoelectrochemical properties of $\mathrm{TiO}_{2}$ nanotube arrays: effect of electrolyte $\mathrm{pH}$ and annealing temperature," Journal of Experimental Nanoscience, vol. 9, no. 3, pp. 230-239, 2014.

[40] K.-S. Ahn, S. Lee, A. C. Dillon, C. E. Tracy, and R. Pitts, "The effect of thermal annealing on photoelectrochemical responses of $\mathrm{WO}_{3}$ thin films," Journal of Applied Physics, vol. 101, no. 9, Article ID 093524, 2007. 

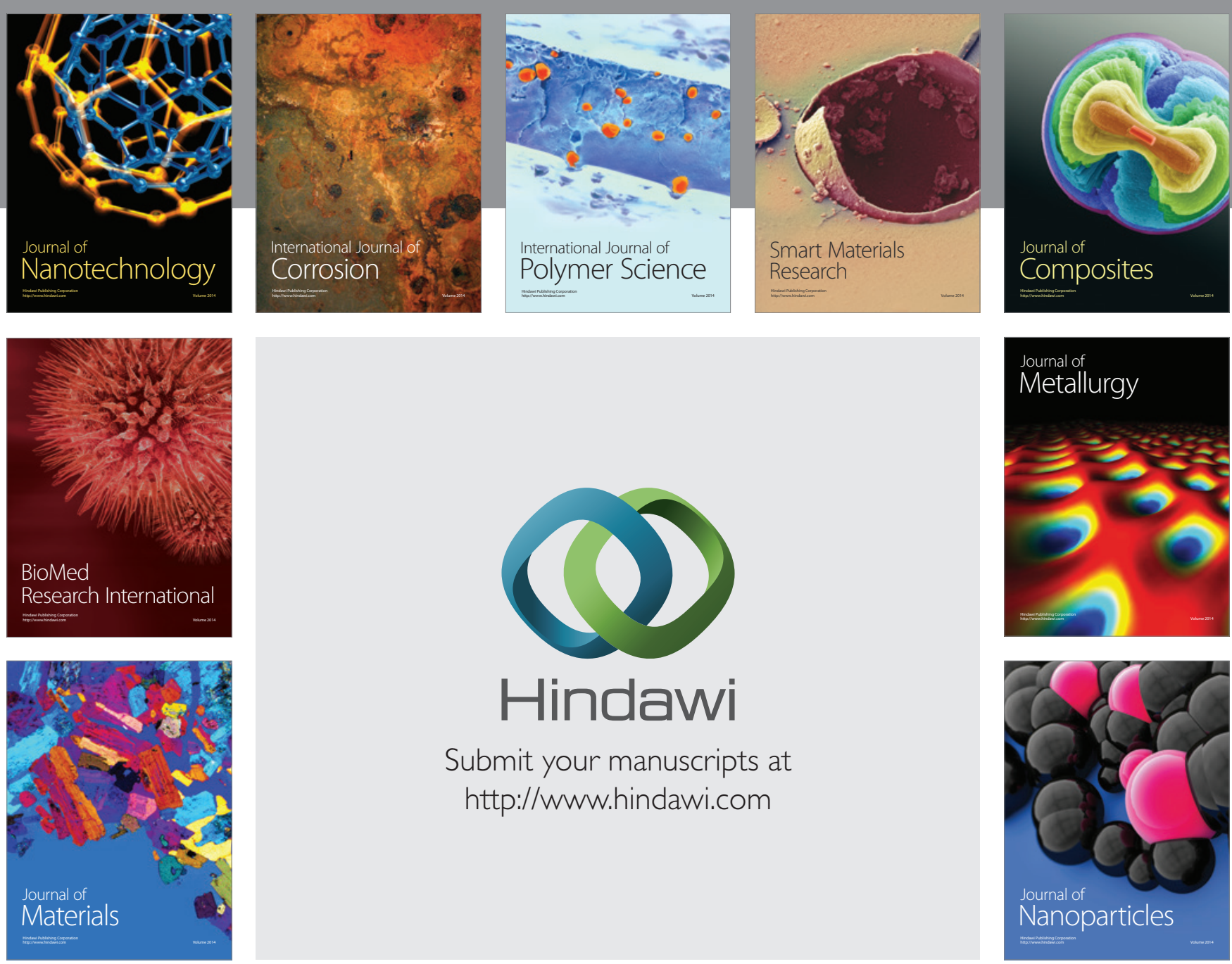

Submit your manuscripts at http://www.hindawi.com
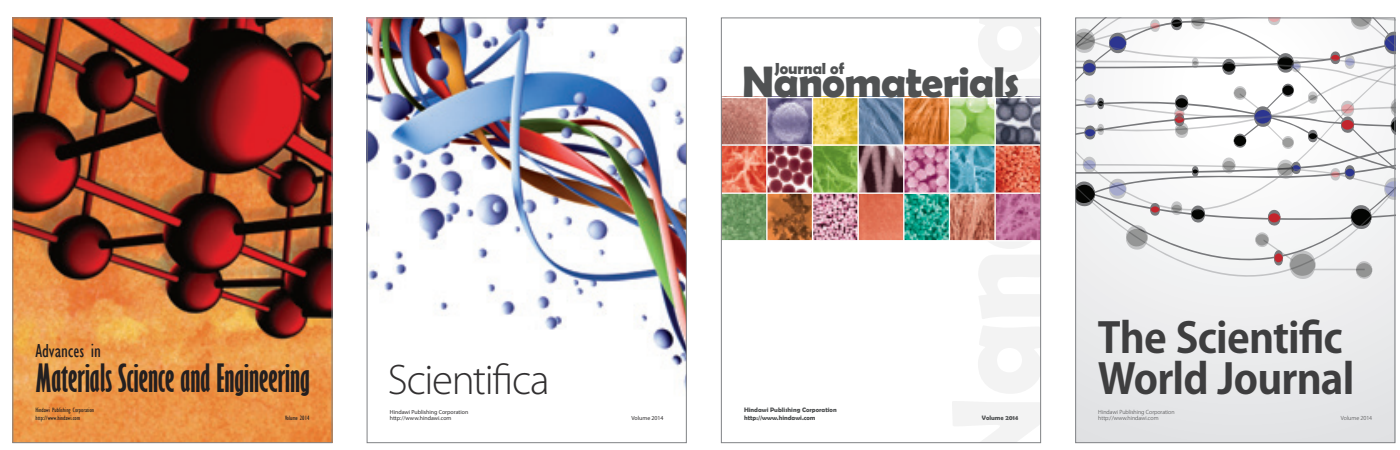

\section{The Scientific World Journal}
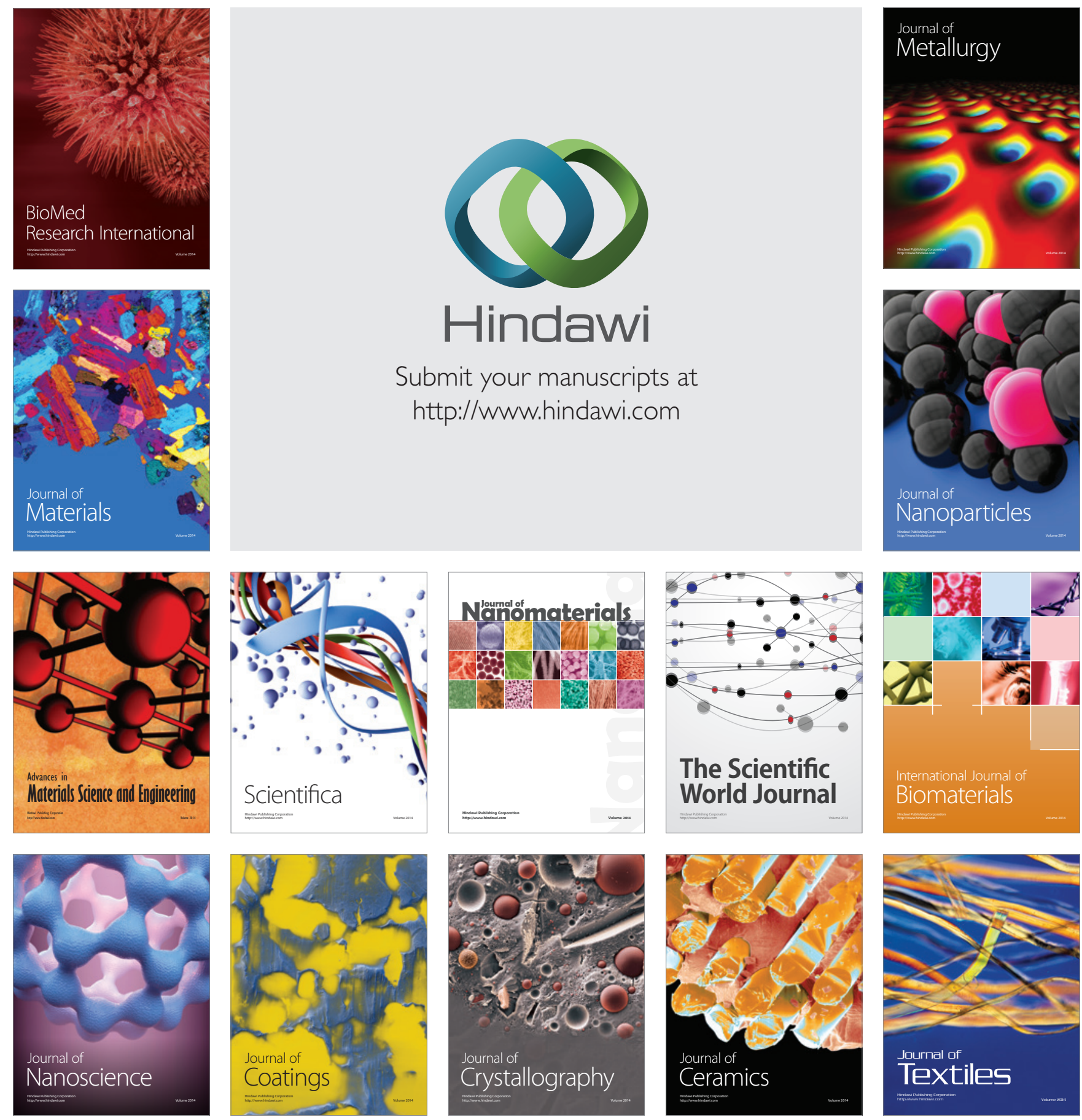